\section{The obesity epidemic in the Americas: making healthy choices the easiest choices ${ }^{1}$}

\author{
Enrique Jacoby ${ }^{2}$
}

Key words: Obesity, exercise, health behavior, life style, urban health, health promotion.

\footnotetext{
1 Based on a presentation made at the Latino Health Forum, Sutter Medical Center of Santa Rosa, Sonoma, California, United States of America, 2 October 2003.

2 Pan American Health Organization, Family and Community Health, Nutrition Unit, Washington, D.C., United States of America. Send correspondence to: Enrique Jacoby, Pan American Health Organization, Family and Community Health, Nutrition Unit, 525 West 23rd Street, N.W., Washington, D.C. 20037, United States of America; e-mail: jacobyen@paho.org
}

In this presentation I will attempt to illustrate the serious impact of the obesity epidemic throughout the Region of the Americas. Particular attention will be paid to the increasing rates of obesity in Latino populations in North America and South America, the underlying factors, and, most importantly, how we can prevent the epidemic from spreading further.

Obesity is behind the three major killers in the United States of America: diabetes, cardiovascular diseases, and hypertension. Obesity also accounts for about 300000 deaths annually (many of them premature deaths), consumes up to US $\$ 100$ billion per year in health care costs, and has quite possibly already surpassed smoking as the country's number one health burden. To top it off, obesity already is taking a major toll on children's health. Diseases that just a few years ago were seen only among adults are now increasingly being diagnosed and treated among youth in the United States (1).

Throughout this presentation I refer to obesity using body mass index, or BMI. This index is obtained by dividing a person's weight in kilograms by the square root of his or her height in meters. A BMI value of 25 or higher defines overweight, and BMI values of 30 and above indicate obesity. This is not a $100 \%$ perfect measure at the clinical level, but it is good enough when we evaluate large population groups.

And, yes, I did say 300000 deaths and US\$ 100 billion in health costs annually in the United States. So why aren't the emergency sirens going off, telling everyone that we've gotten ourselves into huge, serious trouble? You may remember the recent epidemic of SARS, the respiratory infection that started in China. It claimed about 800 lives worldwide, put public health authorities and politicians on alert, made the front pages of newspapers, and was mentioned on television news shows daily until the bug died out.

If you compare 300000 deaths annually with those 800, you might conclude that human beings react to sorrow, pain, and death when it comes to accidents but less so when the conditions kill us slowly. Maybe. That argument is partly true, though. Take the case of tobacco; we don't pass away right after a puff, do we? However, our public health system has been embarked for some time now on a worldwide campaign, wielding all sorts of arms to uproot cigarettes from our lives. That is, we do have the capacity to react and take action against a chronic condition that kills, which is good news indeed. But 
when it comes to the obesity epidemic, I wonder whether the lack of a concrete enemy that we can single out and fight-say a parasite, a virus, or for that matter a cigarette-is what holds us back somehow. Or is it that our present lifestyles are so sacred and rewarding-both personally and financially-that we prefer to shrug and look away from reality?

\section{The emergence of the epidemic of overweight}

As I set out to search for information on obesity among Latino populations in the United States, I was surprised to see that in just the 10 years from 1990 to 2000 the prevalence of obesity among Latinos climbed from $11 \%$ to $21 \%$. But as I continued my search the initial surprise turned to shock as I learned that obesity rates are rapidly climbing among all races and ethnicities in the United States, in all the states of the country, across age groups, in men and women, and in all social and educational groups. It seems as though the forces behind the epidemic of obesity are overpowering our defenses, including the one regarded as the best ally of good health: sound higher education.

That reality is far from being exclusive to the United States. In most Latin American and Caribbean countries, obesity is on the rise as well. For example, in countries such as Chile, Jamaica, Mexico, Peru, and Venezuela, two-thirds of the adult population is overweight or obese-the same level found in the United States. Adolescents are also victims of this epidemic, with levels of overweight that have climbed to $24 \%$ in Mexico, $14 \%$ in Chile, and $12 \%$ in Peru. Who are the most affected, you may wonder. Well, the emerging middle class is, along with the poor who live in cities that are now growing frenetically throughout the Americas. It's no wonder that cardiovascular diseases, diabetes, and hypertension, taken together, are now the main causes of disease and death in Latin America and the Caribbean, a pattern that no one would have imagined back in 1980 (2).

That epidemiologic change in disease has happened over a relatively short period of time. After World War II most Latin American countries experienced rapid urbanization, economic growth, and rising incomes. Many more people adopted Western lifestyles, with major shifts in their diet and physical activity patterns. Progressively abandoning a plant-based tradition, urban diets became higher in fat, sugar, and processed foods. Similarly, jobs that were much less physically demanding became the norm, and television became the dominant form of entertainment. Many countries experienced those changes almost overnight as millions of rural farm workers and their families moved to cities, in search of a better life.
But prosperity did not stop infectious diseases and nutritional problems, such as anemia and stunted growth, which are still public health concerns for many developing countries throughout the Americas. What we are seeing now is that health problems are overlapping, contributing to a vicious cycle that fuels both the obesity epidemic and the epidemic of chronic diseases. How is this possible? Recent research suggests that the connection between undernutrition and chronic diseases starts early in life. Thus, both babies born to undernourished or overweight mothers and children who are shorter in stature seem to be at an increased risk of developing cardiovascular diseases and diabetes some decades later (3).

\section{Is the epidemic of obesity curable?}

Even today, in many countries throughout the Region of the Americas, obesity is still seen as an individual problem, one that is determined mainly by our genes, aided by the sins of gluttony and laziness. The prescription, therefore, has been simple and straightforward: eat less and be more physically active. Those who succeed are praised as examples to follow, while those who succumb to earthly temptations are usually scornfully portrayed as weak and incapable of controlling their own lives. To help us, clinical research and drug development efforts have been after "magic bullets" for more than 30 years: The vision is that people can just pop a pill that will allow them to curb their hunger, shed pounds, and still acquiesce to the intractable coach potato syndrome. Thus far, tampering with our biology has been unsuccessful. Easy weight loss remedies remain the "promised land," and it took the harsh reality of patients' deaths to persuade the United States Government to ban several weight loss drugs. Even drug development experts do not expect any major breakthrough in weight loss remedies in the coming decade, and probably no such drugs will reach the market for at least 20 years (4). I'm sorry to be gloomy, but even if at last the much-awaited miracle drug were discovered, it would be unaffordable and inaccessible to the large majority of people who need it.

\section{How did obesity enter our lives in such a short period of time?}

There have always been obese people in society. However, today's epidemic has happened in the blink of an eye in terms of human history, so it cannot be explained by some evolutionary biological factor. On the contrary, obesity is more the off- 
shoot of rapid technological and cultural changes over the past 30 to 40 years, so understanding these phenomena is crucial if we want to find a sound and sensible solution.

Economic studies highlight the fact that technological change has at once raised the cost of physical activity and lowered the cost of calories. The latter phenomenon is largely driven by improved technology in food production, processing, and marketing. A spectacular production surplus of soybeans and corn during the 1970s provided numerous commercial alternatives to the more typical, time-consuming home-prepared meals. Indeed, prepackaged and frozen foods were made readily available for ease and convenience-from French fries to cookies, and from frozen vegetables to entire meals-producing the so-called "built-in maid service." Most prepackaged foods have a higher caloric content than does any average meal prepared at home. The fast food industry skillfully rode the economic "wave" brought about by these events, helping to fuel the trend of eating tasty, cheap calories outside the home-including fast foods in the schools-as writer Gregg Critser has pointed out in his book entitled Fat Land (5).

In $197025 \%$ of the average food dollar in the United States was spent on food consumed away from home, in 1985 it was 35\%, and by 1996 it had grown to $40 \%$. In 1977 individuals in the United States got $18 \%$ of their calories away from home, but by 1994 that figure had climbed to $34 \%$. Consumption of fat followed a parallel path, going from $19 \%$ of total calories in 1977 to $38 \%$ in 1995 . Soda consumption is tops in contributing to the rise in calorie intake. Between 1977 and 1999 the consumption of sweetened drinks went up $74 \%$ among male teenagers and $65 \%$ among female teens.

One may say, well, that's the choice that people are making. That is partly true, but a great deal has to do with what is being supplied by the market, and with prices. If we look at the food supply in the United States and compare it with what the food pyramid recommends for daily consumption, we see that the supply and the suggested consumption amounts match each other fairly well for cereals, vegetables, dairy products, and even meat. However, that is not so for added fats and added sugars, where the average daily supply exceeds the current dietary recommendations. For example, the market provides $65 \mathrm{~g}$ of fats per person per day, but the food pyramid recommends $41 \mathrm{~g}$ for an average adult 18 years or older. In the case of sugars the relationship is 31 teaspoons available per person per day versus the recommended 21 teaspoons.

Price is an accomplice in this story, as shown by changes in retail food prices over the period of
1985 to 2000. Fruits and vegetables experienced a price increase of $118 \%$, fish of $77 \%$, and cereal products of $75 \%$. In contrast, fats increased only 35\%, and carbonated soft drinks only $20 \%$. The bottom line is that healthy foods are difficult to obtain and that unhealthy ones are ubiquitous, far cheaper, and advertised 24 hours a day (6).

However, it is not only how much or how often we eat that underpins the global epidemic of overweight and associated diseases. It is also a matter of what are we eating. Two important factors are worth mentioning in this regard: high-fructose corn syrup and trans fatty acids. Both have been heralded as major technological accomplishments by food technologists and the agribusiness industry. Cheaper than common sugar (sucrose), high-fructose corn syrup is now the basic sweetener in soda beverages. This makes big profits possible for the soft drink industry, but it is also responsible for triggering high levels of fat (triglycerides) in the bloodstream of individuals as well as possibly triggering insulin resistance and diabetes. Trans fatty acids, on the other hand, were welcomed by the food industry since it is easier to transport hardened oils than liquids and because trans fats extend the shelf life of many products. That's great for the food industry, but there is a downside: Trans fatty acids also clog arteries and accelerate cardiovascular disease.

\section{Improvements in nutrition will require changes in our food environment}

The case of the two products described above highlights the fact that undesirable changes introduced early in the food production chain can challenge consumers' ability to make choices based solely on information.

Important changes in the choices and in the information available to consumers, however, are already taking place at different levels; most of these changes must be credited to scientists in the United States, who are repeatedly showing that the epidemic of obesity cannot be tackled just at the physician's office. The food industry is increasingly acknowledging its role and beginning to take some positive steps, such as offering more salads in fast food restaurants and phasing out trans fats in French fries. In fact, the food industry has played a positive role in alleviating many nutritional deficiencies in the past by making food more affordable and of higher quality through fortification. There is now a new opportunity for them to pitch in and help solve the obesity problem.

In the countries of Latin America some significant efforts are now under way to improve the availability of nutritional foods for the general population. 
In Brazil and Chile the popular school feeding programs that were originally devised to curb undernutrition now are being retooled into obesity prevention ones $(7,8)$. New legislation in Brazil mandates that at least $70 \%$ of such programs' budgets must be spent on fresh fruits and vegetables, with minimal inclusion of processed foods. At the same time most Latin American countries are now engaged in campaigns aimed at strengthening consumer options, through better and simpler labeling of foods, and campaigns that provide the best options based upon available resources. Both of these efforts highlight the benefits of eating a traditional diet that is high in plant sources and fruits and low in fat and meats.

But economic development does not always lead to obesity and associated chronic diseases such as diabetes or hypertension. Economic growth did not have those negative consequences in some $\mathrm{Eu}-$ ropean nations or in Japan or South Korea. The fastpaced industrial expansion of South Korea in the last 15 years has not led to the replacement of the traditional, high-vegetable diet, and we are now seeing rising consumption of fruits and vegetables. This, unfortunately, is not what has happened in many Latin American countries, where we have seen that traditional diets are increasingly abandoned as people adopt the social mores of urban life and become exposed to an environment in which food is no longer in short supply and being chubby is seen as a symbol of good health.

The World Health Organization (WHO) is now seeing new opportunities for change. And the key to those changes is in our food environment. We cannot continue to just preach, "Eat more fruits and vegetables," when a Big Mac is easier to find, cheaper, and probably "cool," if we are to believe the advertising campaigns.

In a nutshell, some of the important changes that we advocate are increasing people's access to and preference for vegetables, fruits, and unrefined grains; creating disincentives to saturated fat production and consumption, and favoring vegetables oils; having effective food labeling and food information; and controlling food advertising that endangers the critical formative years of our children. Some of these measures are in fact starting to occur voluntarily. Hopefully, a growing demand will reinforce them, thus creating the necessary economic incentives for them to be continued. However, regulatory, fiscal, and accountability approaches will be critical in securing food industry compliance with food and advertising standards for a healthy food environment. All of these changes, as a recent WHO report (9) highlights, are much needed. This is particularly true for the poor because they are most at risk and they have the least power to effect change.

\section{Physical inactivity is the other half of the problem}

Physical inactivity has become a major public health problem throughout the Western Hemisphere. The prevalence of inactivity has markedly risen over the last half century as urbanization, motorized transportation, computerization, communications technology, and jobs that are increasingly sedentary are becoming the norm in most urban settings. Physical inactivity is an important risk factor for obesity, cardiovascular disease, colon and breast cancer, and diabetes. It is estimated that in the United States, physical inactivity and poor diet account for at least $14 \%$ of all deaths. Physical inactivity also has substantial economic costs. It has been estimated that physical inactivity is responsible for between $2 \%$ and $6 \%$ of the total health care expenditures in several European countries and also in the United States. In the United States this translates into US\$ 76 billion in potentially avoidable health care expenditures annually (10).

\section{What are the challenges?}

There are four main domains that are related to physical activity: institutional settings, domestic activities, transportation, and leisure time. These domains help us to better understand the problems that we face as well as the choices available for creating and sustaining effective interventions and programs.

The historic trend towards increasingly sedentary work activities is maybe the most important factor behind sedentary lifestyles in the world. Urbanization and economic growth are bringing increased mechanization and digitalization, with work activities becoming less demanding physically than traditional, preindustrial agriculture was. Unless you join the Amish and embrace their unmechanized approach to farming, this pattern is irreversible. This means that alternatives must be sought elsewhere.

Important institutional areas for intervention can be found both in the work environment and in the schools. At work, that can be done by promoting the use of stairs, introducing physical activity breaks during work hours, and creating incentives for using public transportation. In the schools, physical education (PE) courses benefit children by promoting their physical abilities and instilling in them the habit of being active for life. In spite of these merits, over the past decade or so PE has been marginalized in school curricula around the United States. This is a matter of great concern to public 
health and education authorities, and efforts to reverse such negative trends are being implemented.

The pattern of domestic activities, such as cleaning and repairing the home, has also dramatically changed. Activities that were once physically demanding have become much less so, as laborsaving devices become mainstays in most urban households. This area has the potential for public health interventions, but the key to success rests on each individual's conscious decision to resist "convenience and comfort."

Transportation is another domain of interest. Increased reliance on the car is the hallmark of contemporary cities worldwide and a symbol of status as well. In the United States and some European countries, transportation statistics indicate that journeys by car are rising rapidly, while walking and biking are experiencing a steady decline. In the United Kingdom, car trips of less than one mile (1.6 $\mathrm{km}$ ) increased from $4 \%$ of all car trips in the 1980s to nearly $25 \%$ in the year 2000 . Occurring worldwide, this trend is the result of many factors, including seemingly unstoppable urban sprawl, with its inherent problem of ever greater distances to be traveled for work and entertainment. Inadequate mass transit systems contribute to the problem by promoting increasing dependence on personal automobiles.

Fortunately, it is possible to reverse our growing reliance on the automobile. In countries and cities where good public transportation systems exist and incentives for biking are in place, the situation is different. That is the case in Denmark, Finland, and the Netherlands, where bicycle trips account for about $30 \%$ of all trips. Bogotá, Colombia, has developed an extensive network of bike lanes throughout the city, leading to a tripling in bike ridership over the last four years (11).

Changes in the transportation system, along with urban improvements such as pedestrianoriented design and crime control, can also help entire populations fit regular physical activity into their daily lives.

Leisure time is the fourth domain of physical activity. Since many people enjoy outdoor activities and sports, this is an important avenue for promoting physical activity. However, participation in sports is not as common as one might expect. Practicing sports can be difficult because of a lack of time, a shortage of available recreational spaces, and competition from sedentary pastimes such as watching TV and playing computer games. Most people who practice sports, including jogging and walking, do so in open public spaces or on the streets. Therefore, it is of utmost importance to pay attention to the availability of public recreational areas and to safety issues.

\section{Prevention is the best "drug" available}

Although the main focus of this presentation has been on prevention, we should not lose sight of the fact that control of chronic diseases and obesity will continue to be an important concern to health systems and practitioners. Recent studies suggest that efficacious early treatment for hypertension, diabetes, and serum cholesterol can result in positive health outcomes and can also reduce health costs. Given that only $40 \%$ of those diagnosed with high blood pressure in the United States have their blood pressure adequately controlled, there is much room for improvement. Good timing and appropriate treatment practices can certainly make the difference in the lives of millions of people.

Let's go back to the topic of prevention. If we want to succeed, we have to come to grips with the fact that critical behaviors associated with eating and physical activity respond to a variety of factors, not only good information. In fact, individuals generally consider health issues as just one of many factors when deciding what to eat, whether to exercise, or if they should quit smoking. Eating more fruits will bring health 20 years down the road. However, in considering whether to do that, a person must deal with many competing factors, including such short-term ones as the convenience and immediate reward of fast foods, their affordable prices, and their super-sizing. Our task, then, is to devise public health programs that take into account not only the factors that are associated with health motives but rather all the factors that influence key human behaviors.

That is why the promotion of healthy eating is increasingly addressing environmental factors such as the availability of fresh produce, prices, and marketing. However, I want to mention here one element that is part of the environment and that is critical to behavioral change: values. One of the ingredients in making behavioral decisions is what others are doing. This by itself can shift a decision when a person appraises the costs and benefits of any behavioral change. Consider what Dr. Alfred Sommer, the dean of the Johns Hopkins University School of Public Health, has to say in this regard: "It is a lot easier to avoid risky behavior when everyone else does as well, and when the environment doesn't support it. That's precisely why tobacco use, red meat consumption, and DUI [driving under the influence of alcohol] have dramatically declined in the U.S. [United States]." (12).

Good prevention, therefore, requires strong foundations in our communities and society at large. We now have very good examples in various parts of the world, and that's encouraging for us at 
the World Health Organization (WHO) and the Pan American Health Organization (PAHO), which is the WHO's Regional Office for the Americas. Some of those examples come from initiatives in countries as diverse as Finland, Mauritius, and Singapore. These countries started national policies to improve the diet of their citizens, with impressive results. In Finland and Mauritius, national policy and regulatory measures have improved the quality of their market supply of oils, thus reducing highly saturated fats and promoting alternative polyunsaturated and monounsaturated vegetable oils. In those two countries those actions resulted in a decrease of about $60 \%$ and $25 \%$, respectively, in mortality from cardiovascular diseases. Going one step further, in July 2003 the Ministry of Commerce of Finland issued a ban on all trans fatty acids in the Finnish market, a measure that is expected to further improve cardiovascular health in the short run. Singapore, after a decade-long effort to reduce obesity among school-age children, is now beginning to see a slow reversal in the number who are overweight.

Here in the United States, public health officials are talking more directly about the need for changes in diet and physical activity. For example, Tommy G. Thompson, the Secretary of Health and Human Services, referred to the fast food industry in an interview last May and said, "We're asking them to step up and see if they can do innovative things, like encouraging their customers to eat properly and to exercise." He added, "McDonald's is putting more salads on their menus and diversifying, and I think that is a wonderful sign."

By the same token, the decision of the California Senate to restrict sales of soda at middle schools and elementary schools, which should take effect 1 July 2004, is a landmark decision. This decision could provide a positive signal not only to other states in the United States but to schools around the world.

We know obesity is a grave public health problem. We also have a rather good idea of what its causes are and what needs to be done. What is still in short supply are societal values that clearly recognize that obesity is an important problem and that we should do something about it, even when that entails changing aspects of our present lifestyles. I'm confident, however, that we are starting to move in the right direction.

The WHO is taking action to tackle the epidemic of chronic diseases. For example, the WHO is now engaged in a worldwide consultation process with public and private institutions, with the aim of developing a Global Strategy on Diet, Physical Activity and Health, under the guiding principle of "making healthy choices the easiest choices for all." A multinational consensus on the initiative is expected by May 2004, when the 2004 World Health Assembly will take place. The Global Strategy on Diet, Physical Activity and Health will provide a much-needed rubric under which family, community, and regional efforts will be sustainable and successful in addressing the obesity epidemic.

\section{SINOPSIS}

\section{La epidemia de obesidad en las Américas: lograr que las elecciones más sanas sean las más fáciles}

En los Estados Unidos de América y en la mayoría de los países de América Latina y el Caribe se está observando un aumento de la obesidad y otros trastornos con los que esta se asocia, tales como la diabetes, la hipertensión arterial, y las enfermedades cardiovasculares. Tomados en conjunto, estos trastornos causan dos tercios de todas las muertes y menoscaban enormemente los presupuestos destinados a la atención sanitaria, así como la productividad económica y la calidad de la vida. Consumir una dieta sana y mantenerse físicamente activo son maneras eficaces de evitarlos. Cada vez son más quienes opinan que es tarea prioritaria de la salud pública adoptar un enfoque preventivo para combatir estas afecciones.

Lo que resulta difícil es no limitarse a entregarle al paciente una receta personal para que cambie de conducta. No tiene mucho sentido predicarle que "coma más frutas y verduras" cuando los alimentos procesados de mala calidad $y$ los bocadillos para entre las comidas se venden por todas partes, son más baratos y hasta tienen algo de chic. Por consiguiente, hay que procurar que haya mayor acceso a y predilección por las verduras, frutas y granos sin refinar; desincentivar la producción y el consumo de alimentos a base de grasas saturadas; crear incentivos que fomenten el consumo de aceites de origen vegetal; rotular bien los productos y proporcionar información adecuada sobre ellos; $y$ regular la propaganda dirigida a los niños, que son impresionables y no saben distinguir entre lo propagandístico y lo recreativo. De hecho, algunas de esas medidas se están empezando a producir voluntariamente. La creciente demanda del público las reforzará, pero también harán falta medidas reguladoras y fiscales y la toma de responsabilidad frente al público.

Asimismo, podría parecer inútil aconsejarles a las personas que hagan más ejercicio cuando sienten que no tienen suficiente tiempo y dinero para practicar deportes y cuando se corre peligro en las calles. Hoy en día hay numerosas opciones que facilitan la decisión de mantenerse activo. En el trabajo algunas son el uso de las escaleras, la introducción de pausas para actividades físicas, y la creación de incentivos a favor del uso del transporte público. En las escuelas, las clases de gimnasia benefician a los niños porque los ayudan a desarrollar sus habilidades físicas y porque les inculcan de por vida el hábito de ser activos. En países y ciu- 
dades de Europa donde hay buenos sistemas de transporte e incentivos para montar en bicicleta, los paseos en bicicleta $y$ a pie representan alrededor de $30 \%$ de todos los traslados de un lugar a otro en un día en particular. En Bogotá, Colombia, se ha creado una extensa red de rutas para ciclistas por toda la ciudad, gracias a lo cual el ciclismo se ha triplicado en los últimos cuatro años.
La obesidad y otras enfermedades crónicas son problemas de salud pública muy alarmantes. Sabemos por qué estos trastornos se han vuelto más frecuentes en años recientes, qué los produce y qué medidas se deben tomar para contrarrestarlos, pero aún no abundan los valores sociales que impulsan las acciones para prevenirlos.

\section{REFERENCES}

1. United States of America, Centers for Disease Control and Prevention, Division of Nutrition and Physical Activity. Overweight and obesity: obesity trends [Internet site]. Available from: http:// www.cdc.gov/nccdphp/dnpa/obesity/ trend/index.htm. Accessed 15 December 2003.

2. World Health Organization. World health report 2002: reducing risks, promoting healthy life. Geneva: WHO; 2002.

3. World Health Organization. Programming of chronic disease by impaired fetal nutrition: evidence and implications for policy and intervention strategies. Geneva: WHO; 2002.

4. Gura T. Obesity drug pipeline not so fat. Science. 2003;299(5608):849-52.
5. Critser G. Fat land: how Americans became the fattest people in the world. Boston: Houghton Mifflin Co.; 2003.

6. Putnam J, Allshouse J, Kantor LS. U.S. per capita food supply trends: more calories, refined carbohydrates and fats. Food Rev. 2002;25(3):2-15.

7. Coitinho D, Monteiro CA, Popkin B. What Brazil is doing to promote healthy diets and active lifestyles. Public Health Nutr. 2002;5(1A):263-7.

8. Uauy R, Albala C, Kain J. Obesity trends in Latin America: transition from under- to overweight. J Nutr. 2001;131: 893S-9S.

9. World Health Organization. Diet, nutrition and the prevention of chronic diseases, report of a joint WHO/FAO expert consultation. Geneva: WHO; 2003.
10. Pratt M, Jacoby ER, Neiman A. The challenges of promoting physical activity in the Americas. Food Nutr Bull. Forthcoming 2004.

11. Gonzáles B, ed. Bogotá cómo estamos? Cambios en la calidad de vida de la ciudad 2000-2002. Bogotá: Casa Editorial El Tiempo, Fundación Corona y Cámara de Comercio de Bogotá; 2002.

12. Sommer A. Health, behavior, and risk. Johns Hopkins Public Health Mag. 2003; 48.

Manuscript received 22 December 2003. Accepted for publication on 27 January 2004

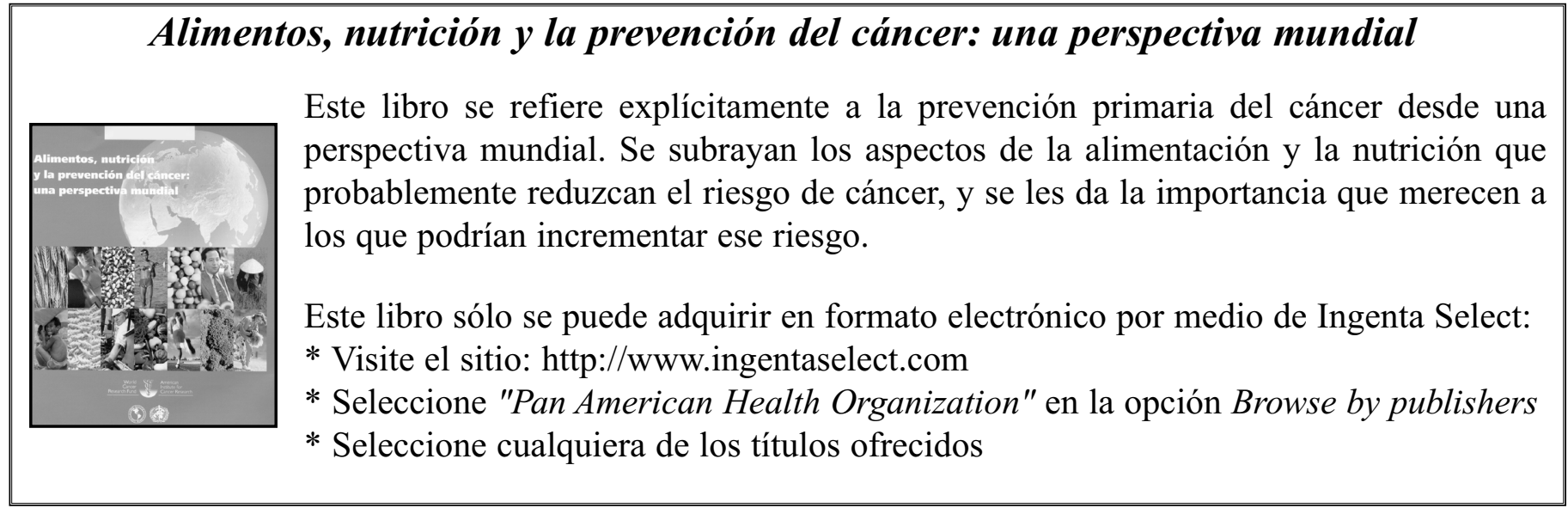

